\title{
A construção narrativa e a desconstrução da identidade em $O$ Olho Mais Azul, de Toni Morrison
}

\section{The narrative construction and deconstruction of identity in The Bluest Eye by Toni Morrison}

\author{
Cleideni Alves do Nascimento* \\ Marly Catarina Soares**
}

\begin{abstract}
Resumo: O objetivo deste artigo é analisar a estrutura arquitetônica do romance O Olho Mais Azul, da escritora norte-americana Toni Morrison , e a forma como sua organização contribui para a desconstrução da personagem principal - Pecola. Esta análise é baseada na teoria de Bakhtin sobre a forma composicional e arquitetônica do romance. A escritora desenvolve uma sequência narrativa que, ao mesmo tempo em que desconstrói a personagem, suaviza esse processo através da humanização das outras personagens responsáveis pela desconstrução da identidade de Pecola. É como uma cadeia de subjetividades, uma influenciando a outra. Há dois narradores no romance: um é o narrador-personagem e o outro é um narrador onisciente. Eles dão equilíbrio e harmonia à história. A estrutura arquitetônica do romance é parte do recurso estilístico usado para caracterizar a personagem principal.
\end{abstract}

Palavras-chave: Narrativa de ficção. Identidade. Estudos Literários.

Abstract: The aim of this paper is to analyze the architectural structure of the novel The Bluest Eye by the North American writer Toni Morrison, and how its organization contributes for the deconstruction of the main character - Pecola. This analysis is based on Bakhtin's theory about the romance compositional and architectural form. The writer develops a narrative sequence that at the same time deconstructs the character and smoothes this process by humanizing the other characters responsible for her deconstruction. It is like a chain of subjectivities, one influencing the other. There are two narrators in the novel: one is a narrator-character and the other is an omniscient narrator. They give balance and harmony to the history. The romance architectural structure is part of the stylistic resource used to characterize the main character.

Keywords: Narrative Fiction. Identity. Literary Studies.

\section{Introdução}

\footnotetext{
${ }^{1}$ A autora foi a primeira mulher negra a receber o Prêmio Nobel de Literatura em 1993.

${ }^{*}$ Mestranda. Universidade Estadual de Ponta Grossa - UEPG. E.mail: cleideni_nascimento@yahoo. com.br

*** Professora. Doutora. Universidade Estadual de Ponta Grossa - UEPG. E.mail: marlycs@yahoo.com.br
} 
Este artigo tem por objetivo analisar a estrutura narrativa do romance $\mathbf{O}$ Olho Mais Azul (1970), da escritora norte-americana Toni Morrison, e mostrar que a maneira como a narrativa é construída tem uma função específica dentro do romance. Sua função é mostrar um processo de desconstrução identitária, pois enquanto a narrativa vai sendo desenvolvida, ela age na desconstrução da identidade da personagem principal da história - Pecola. Os acontecimentos e o relacionamento das outras personagens em relação à menina atuam diretamente nesse processo de desconstrução.

A autora nos apresenta relatos da vida de cada personagem que tem influência sobre Pecola, contando suas misérias, frustrações e sofrimentos, com a finalidade de humanizá-las. Ao mostrar suas histórias, a autora deixa implícito que elas não são as únicas responsáveis pelas pessoas que se tornaram, mas que suas subjetividades foram formadas no meio social em que viviam, assim como a subjetividade de Pecola se molda a partir do que ela recebe do seu meio social..

Para conduzir o romance, a autora utiliza duas vozes narrativas. A primeira e predominante é a voz de um narrador onisciente em terceira pessoa, responsável pela caracterização de todas as personagens que desconstroem Pecola. A segunda é a voz de Claudia, narradora-personagem que, quando nos conta a história, já não é mais a menina de nove anos que participou daquele momento da vida de Pecola. Porém, ao construir a narrativa de Claudia, a autora reconstrói a linguagem infantil das meninas dando preferência à pureza e à autenticidade que as crianças tão naturalmente conseguem expressar. É com esse recurso que a autora consegue dar mais leveza e um pouco de alegria à obra.

Além das vozes dos dois narradores, encontramos no romance diversas outras vozes, recriadas a partir de diálogos diretos ou de relatos de cartas. O recurso do diálogo direto é utilizado tanto pelo narrador onisciente quanto por Claudia. Mas o recurso de relatos de carta é usado somente pelo narrador onisciente, com o objetivo de conferir maior veracidade à caracterização da personagem enfocada.

Considerando a estrutura e as vozes narrativas, daremos início à análise do romance, mas antes disso apresentaremos alguns conceitos teóricos que embasaram o presente estudo. Para tanto, fundamentamo-nos nos conceitos de Forma Composicional e Arquitetônica apresentados por Mikhail Bakhtin em seu livro Questões de Literatura e Estética: a teoria do romance (1998). 
Quando Bakhtin (2003, p. 216) escreve sobre os gêneros do discurso, ele diz que todo e qualquer gênero é formado por um conteúdo temático, pelo estilo da linguagem e por uma construção composicional.

O romance, gênero literário do qual estamos tratando, é definido por Bakhtin da seguinte forma:

O romance é uma forma puramente composicional de organização das massas verbais, por ela se constituir num objeto estético a forma arquitetônica da realização artística de um acontecimento histórico ou social, que constitui uma variante da forma da realização épica (BAKHTIN, 1998, p. 24).

Dentro da composição romance encontramos um tema e um estilo de linguagem. Os temas da literatura somam pouco mais de meia dúzia, isso quer dizer que é de uma variedade limitada. Levando esses fatos em consideração, poderíamos pensar, então, que todos os romances são iguais. No entanto, há um diferencial importantíssimo a ser considerado: o estilo, ou o que Bakhtin chama de forma arquitetônica. O que faz a diferença não é o que se vai dizer, mas como se vai dizer.

A forma arquitetônica diz respeito ao trabalho artístico feito pelo escritor para dar singularidade à sua obra. Esse trabalho envolve a linguagem ou linguagens a serem escolhidas; a disposição dos fatos na narrativa; as vozes narrativas que conduzirão a história. Esses itens atenderão à intenção do autor como um recurso para dar mais expressividade literária à obra e para conduzir o leitor no sentido pretendido.

O mundo que o escritor constrói dentro de um romance deve ser detalhadamente arquitetado, sob pena de não se sustentar sobre as próprias bases por ele erguidas. Sua matéria-prima não é de fácil manipulação, pois a palavra é sempre lacunosa e fragmentária em relação àquilo que realmente se quer dizer. Ao reconstruir o mundo, o escritor deve chegar o mais próximo possível das linguagens sociais. De acordo com Bakhtin (1998, p.74), “O romance é uma diversidade social de linguagens organizadas artisticamente, às vezes de línguas e de vozes individuais".

Quando essas linguagens são organizadas em um romance ele assume seu caráter prosaico, sua dialogicidade interna. A prosa transcende a obra e cumpre sua função social que é dialogar com o leitor. Bakhtin (1998, p. 93) diz 
que no romance a dialogicidade interna torna-se um dos aspectos essenciais do estilo prosaico e presta-se a um elaboração literária e específica.

Dentro da composição de um romance a história é parte indispensável, pois sem ela a compreensão do romance se torna quase impossível. Uma mesma história pode ser contada de diversas maneiras, mas o foco da história sempre recai sobre os fatos, e não sobre a causalidade. Forster (1969, p. 21) diz que a história é o mais vulgar e simples dos organismos literários, contudo é o máximo divisor comum a todos os complicados organismos conhecidos como romances. Reforçando essa ideia, temos o posicionamento de Eco (1994, p. 42) que diz: "Um texto narrativo pode não ter enredo, mas é impossível que não tenha história ou discurso".

Apesar de imprescindível, somente a história não é suficiente para construir um bom romance. Não basta dispor os fatos em uma sequência temporal que alimente a curiosidade do leitor em saber o que vem depois. É necessário buscar e refletir sobre as suas causas. Esse papel é desenvolvido pelo enredo. Ele é responsável pela representação dos valores morais que dizem respeito aos atos da sociedade. A ênfase do enredo recai sempre na causa de um acontecimento, e não no fato em si.

Quando Bakhtin fala sobre a forma composicional e a arquitetônica, ele diz que a primeira atende ao caráter técnico da obra e que ela se submete à segunda.

As formas composicionais que organizam o material têm um caráter teleológico, utilitário, como que inquieto, e estão sujeitas a uma avaliação puramente técnica, para determinar quão adequadamente elas realizam a tarefa arquitetônica. A forma arquitetônica determina a escolha da forma composicional. (BAKHTIN, 1998, p. 25).

Contudo, Bakhtin (ibidem) diz que não se pode concluir que a forma arquitetônica existe em algum lugar sob um aspecto acabado e que pode ser realizada independente da forma composicional. Poderíamos dizer, então, que a forma arquitetônica seria o trabalho artístico que o escritor faz entrelaçando a história e o enredo. Passaremos agora à análise do romance.

\section{Texto introdutório do romance}


Esta é a casa. É verde e branca. Tem uma porta vermelha. É muito bonita. Esta é a família. A mãe, o pai, Dick e Jane moram na casa branca e verde. Eles são muito felizes. Veja a Jane. Ela está de vestido vermelho. Ela quer brincar. Quem vai brincar com Jane? Veja o gato. Está miando. Venha brincar. Venha brincar com a Jane. O gatinho não quer brincar. Veja a mãe. A mãe é muito boazinha. Mãe, quer brincar com a Jane? A mãe ri. Ria, mãe, ria. Veja o pai. Ele é grande e forte. Pai, quer brincar com a Jane? O pai está sorrindo. Sorria, pai, sorria. Veja o cachorro. Auau, faz o cachorro. Quer brincar com a Jane? Veja o cachorro correr. Corra, cachorro, corra. Olhe, olhe. Aí vem um amigo. O amigo vai brincar com a Jane. Eles vão jogar um jogo gostoso. Brinque, Jane, brinque. (Grifos nossos)

Esta é a casa é verde e branca tem uma porta vermelha é muito bonita esta é a família a mãe o pai dick e jane moram na casa branca e verde eles são muito felizes veja a jane ela está de vestido vermelho ela quer brincar quem vai brincar com jane veja o gato está miando venha brincar venha brincar com a jane o gatinho não quer brincar veja a mãe a mãe é muito boazinha mãe quer brincar com a jane a mãe ri ria mãe ria veja o pai ele é grande e forte pai quer brincar com a jane o pai está sorrindo sorria pai sorria veja o cachorro auau faz o cachorro quer brincar com a jane veja o cachorro correr corra cachorro corra olhe olhe aí vem um amigo o amigo vai brincar com a jane eles vão jogar um jogo gostoso brinque jane brinque

Estaéacasaéverdeebrancatemumaportavermelhaémuitobonitaestaéafamíliaamãeopaidickejanemoramnacasabrancaeverdeelessãomuitofelizesvejaajaneelaestádevestidovermelhoelaquerbrincarquemvaibrincarcomjanevejaogatoestámiandovenhabrincarvenhabrincarcomajaneogatinhonãoquerbrincarvejaamãeamãeémuitoboazinhamãequerbrincarcomajaneamãeririamãeriavejaopaieleégrandeefortepaiquerbrincarcomajaneopaiestásorrindosorriapaisorriavejaocachorroauaufazocachorroquerbrincarcomajanevejaocachorrocorrercorracachorrocorraolheolheaívemumamigooamigovaibrincarcomajaneelesvãojogarumjogogostosobrinquejanebrinque

(MORRISON, 2003, p. 7. grifos nossos)

O texto acima é a parte inicial do romance O Olho Mais Azul. Trata-se de um trecho retirado de uma popular cartilha de alfabetização utilizada entre 1930 e 1970 nos Estados Unidos. Dick e Jane eram as carismáticas personagens das histórias contadas nessa cartilha. Duas crianças brancas que vivem felizes 
em uma família média americana. Em contrapartida, personagens negras ou de outras nacionalidades não haviam sido introduzidas na cartilha antes de 1965 , época em que a popularidade da cartilha já estava em declínio. Esse fato se explica pelo período histórico em que a cartilha existiu, pois somente a partir dos anos 1970 os negros conseguiram conquistar mais espaço e direitos na sociedade norte-americana.

Não é por mera ilustração que Toni Morrison escolhe esse texto para dar início ao seu romance. É através dele que a autora mostra um paradoxo que é uma história que se passa na década de 1940, vivida por uma família negra muito pobre. Ao analisarmos o texto acima, podemos perceber que ele apresenta muitas palavras positivas que dão a sensação de felicidade, entre elas: casa bonita; eles são muito felizes; uma mãe boazinha que ri; um pai grande e forte que sorri; um amigo que joga um jogo gostoso. Além dos animais de estimação que também fazem parte da família. Jane é a personagem central, uma criança feliz que gosta de brincar.

Quando se lê esse texto inicial, não é possível entender qual é seu sentido. Ele parece bobo e sem finalidade. Mas dando continuidade à leitura, pode-se perceber qual foi a intenção da autora. Ela desmonta o texto ao longo de quatro grandes capítulos que correspondem às estações do ano, a começar pelo Outono. Cada trecho é usado como parte introdutória, trazendo em si o assunto que será tratado. As partes postas em negrito na primeira versão do texto acima correspondem aos assuntos que serão tratados ao longo do romance. A personagem principal deixa de ser Jane e passa a ser Pecola. Ao desconstruir o texto da cartilha, constrói-se a história de Pecola, que é o oposto da história de Jane.

Mas qual é a razão de haver três versões do texto inicial em sequência? A primeira é o texto pontuado, organizado e claro. Apresenta uma harmonia que corresponde à vida da família. A segunda perde toda a pontuação e as letras maiúsculas (exceto a primeira) e tem sua organização abalada. E o último, sem pontuação, sem maiúsculas e sem espaço, representa a total perda de organização e harmonia. É uma prévia do que vai acontecer com a vida da outra família que será retratada no romance. Saída de um modelo de família idealizado para a entrada de um modelo de família real.

Todas as partes que têm um trecho introdutório extraído do texto inicial são narradas por um narrador onisciente. É ele quem nos relata a realidade da vida de Pecola em relação às pessoas que fazem parte do seu convívio. 
As partes que não possuem trechos introdutórios são de responsabilidade da narradora-personagem Claudia.

\section{Texto de apresentação do romance}

Cá entre nós, não houve cravos-de-defunto no outono de 1941. Na época pensamos que era porque Pecola ia ter o bebê do pai dela que os cravos-de-defunto não cresceram. Um pequeno exame e muito menos melancolia nos teriam provado que as nossas sementes não foram as únicas que não brotaram: as de ninguém brotaram. Nem mesmo os jardins que ficavam de frente para o lago exibiram cravos-de-defunto naquele ano. Mas estávamos tão profundamente preocupadas com a saúde e o nascimento do bebê de Pecola que não conseguíamos pensar em outra coisa que não fosse a nossa magia: se plantássemos dizendo as palavras corretas, as sementes brotariam e daria tudo certo.

Passou-se um longo tempo até que minha irmã e eu admitíssemos para nós mesmas que não ia sair broto algum das nossas sementes. Quando entendemos isso, só aliviávamos nossa culpa com brigas e acusações mútuas sobre a responsabilidade pelo fato. Durante anos achei que minha irmã tinha razão: a culpa foi minha. Eu as tinha plantado fundo demais na terra. Jamais ocorreu a nenhuma das duas que a própria terra pudesse estar improdutiva. Tínhamos jogado as sementes no nosso canteiro de terra negra exatamente como o pai de Pecola havia jogado as suas no canteiro de terra negra dele. Nossa inocência e nossa fé não foram mais produtivas do que a luxúria ou o desespero dele. $\mathrm{O}$ que está claro agora é que, de toda a nossa esperança, do medo, luxúria, amor e pesar, não resta nada além de Pecola e da terra improdutiva. Cholly Breedlove está morto; nossa inocência também. As sementes murcharam e morreram; o bebê dela também.

Não há realmente mais nada a dizer - a não ser por quê. Mas como é difícil lidar com o porquê, é preciso buscar refúgio no como.

$$
\text { (idem, p. 9, grifos nossos) }
$$

Este texto vem logo após o texto introdutório. Ele também não faz parte dos capítulos do romance. Trata-se de uma apresentação que traz um resumo de toda a história que será desenvolvida posteriormente. Atentemos para a marcação temporal em negrito. Ela mostra que se trata de um passado já distante. Temos o ano de 1941 e sabemos que Passou-se um longo tempo..., Durante anos... até que nos é mostrado um agora. Então, chegamos ao 
presente da enunciação, que é quando a história começa a ser contada. Quanto tempo se passou com precisão, não saberemos. Mas sabemos que foi tempo suficiente para matar a inocência e destruir toda e qualquer esperança infantil.

Claudia, a narradora, se dirige ao leitor com certo tom de intimidade, como alguém que vai revelar um segredo. Podemos perceber isso pela expressão Cá entre nós... usada por ela no início. Claudia nos revela já no início um caso de incesto. Pecola iria ter um bebê do pai dela. Mas a gravidade do caso acaba por ser amenizada devido à ingenuidade da narradora e de sua irmã Frieda quando o fato ocorreu. Elas estavam preocupadas em descobrir por que seus cravos-de-defunto não floresceram, e Pecola estar esperando um bebê do pai dela poderia ser um dos motivos. $\mathrm{Na}$ época, elas ainda não conseguiam perceber a seriedade do acontecimento. Estavam felizes e torciam para que o bebê nascesse bem.

Observemos o tom metafórico que há no texto. Fala-se em sementes, cravos-de-defunto, terra negra, canteiro, brotar, crescer, improdutiva, murchar, morrer. Todas essas palavras remetem ao ato de plantar. Porém temos no texto dois sentidos diferentes para plantar. Vejamos o trecho a seguir: "Tínhamos jogado as sementes no nosso canteiro de terra negra exatamente como o pai de Pecola havia jogado as suas no canteiro de terra negra dele." Claudia e Frieda realmente semearam um canteiro de cravos-de-defunto e esperaram ansiosamente pela beleza do florescimento. Já o pai de Pecola semeou toda a sua miséria e angústia de viver no canteiro que na verdade era a própria filha. O que se poderia esperar que florescesse? A beleza não seria.

Por analogia, poderíamos também nos ver como canteiros. Cada um produziria o fruto das sementes que outros lançaram em nosso solo. Nossa identidade e subjetividade seria resultado daquilo que recebemos ao longo das nossas vidas. Foi o que aconteceu com Pecola. Claudia encerra esse texto dizendo que buscará refúgio no como tudo aconteceu, pois é muito difícil lidar com o porquê, ou seja, ela nos apresentará os fatos e cabe ao leitor fazer suas próprias suposições em relação aos motivos que levam as pessoas a agirem de tal ou qual maneira. Ela dá ao leitor a opção de saber como tudo aconteceu. Ele pode dar continuidade à leitura ou então simplesmente parar, pois ele já sabe do assunto que se trata.

A narrativa percorre o tempo de um ano e está dividida em quatro capítulos que correspondem às estações do ano. Durante esse período, serão apresentadas diversas situações relatadas pelos narradores, que mostram exem- 
plos de atitudes que contribuíram para o aniquilamento moral e psicológico de Pecola. Obviamente, não podemos dizer que todas as coisas que aconteceram nesse ano foram as únicas responsáveis pelo seu massacre pessoal, mas elas são um recorte do que havia sido a ainda recente vida de Pecola. Além disso, não podemos nos esquecer de que o que recebemos são as lembranças de Claudia do pouco tempo em que ela teve contato com a personagem principal.

É Claudia quem sempre inicia os capítulos, todos eles. Passando a narrativa, na sequência, para o narrador onisciente. Ela retoma apenas o último capítulo, pois é ela quem encerra a história.

\section{Capítulo Outono}

É essa a estação que inicia a narrativa. Esse capítulo é dividido em três partes: a primeira narrada por Claudia e as outras duas, pelo narrador onisciente. Veremos, sucintamente, cada uma delas.

Ao narrar, Claudia - a narradora personagem - sempre fala sobre sua própria vida, suas impressões, suas opiniões e descontentamentos. No entanto, ela mescla a sua história com a de Pecola. Suas histórias têm o mesmo contexto social e histórico, fortemente marcado pelo desprezo racial. Claudia resiste à opressão racial, mas Pecola sucumbe ao seu peso. Embora o papel de Claudia seja muito importante como contraponto ao que acontece com Pecola, nos deteremos nesse trabalho aos fatos que têm relação especificamente com Pecola. No que diz respeito à identidade, é ela quem tem a sua desconstruída no decorrer da história.

Em Outono há dois episódios narrados por Claudia que mostram, ainda que sutilmente, o desejo de Pecola de ser diferente fisicamente. E, submerso nesse desejo, há o desejo mais profundo de ser amada. Ela acreditava que essa mudança aparente e superficial faria com que as pessoas a tratassem com amor e carinho, demonstrações de afeto que ela não recebia. Há nesse desejo de mudança física uma negação de si mesma. Desejar ser o outro é dizer que não se tolera aquilo que realmente se é.

O primeiro episódio ocorre quando Pecola passa alguns dias na casa de Claudia por determinação da justiça, pois seu pai, bêbado e violento, havia incendiado a casa e deixado a sua família na rua. Um dia Claudia e Frieda oferecem bolachas a Pecola e trazem também uma xícara de leite decorada 
com a face da atriz mirim Shirley Temple. Uma situação muito banal, não fosse a reação de Pecola diante da xícara.

Frieda lhe trouxe quatro bolachas num pires e leite numa xícara branca e azul com a Shirley Temple. Ela demorou um longo tempo para tomar o leite, olhando ternamente para a silhueta do rosto com covinhas de Shirley Temple. Frieda e ela conversaram, enternecidas, sobre como a Shirley Temple era lindinha. (MORRISON, 2003, p. 22)

Sabíamos que ela gostava da xícara com a Shirley Temple e aproveitava toda oportunidade para tomar leite nela, só para segurar e ver o rosto meigo da Shirley. (idem, p. 27)

A mãe de Claudia e Frieda ficou furiosa e não conseguia entender como de um dia para o outro três garrafas de leite poderiam desaparecer, acabar. Pecola bebia o leite não por gula, mas para estender o tempo de contemplação da imagem de Shirley Temple que havia na xícara. A pequena atriz mirim era tudo que ela gostaria de ser, uma adorável garota branca de olhos azuis e cabelos encaracolados. Além disso, o leite também tem uma simbologia pela sua própria cor, um líquido branco que contrasta com a pele negra de Pecola. Há no gesto repetitivo de tomar leite naquela xícara um rastro de obsessão, como um ritual antropofágico de querer tornar-se aquilo que se devora. E ao querer ser o outro, Pecola nega sua própria identidade como negra.

Outro fato acontecido nesse período passado na casa de Claudia é a primeira menstruação de Pecola. Episódio que se torna engraçado pela cena que as meninas criam em torno desse acontecimento. Pecola não entende o que está acontecendo e acha que vai morrer. Mas Frieda, que já sabia do que se tratava, explica para Pecola o que é menstruação. "Nããããão. Não vai morrer. Isso só quer dizer que você pode ter um bebê!” (idem, p. 31) Ao fim daquele dia, essas palavras de Frieda ainda ecoavam na mente de Pecola. Ela pergunta a Frieda como isso acontece. Frieda responde, naturalmente, que alguém tem que amá-la. "Como é que se faz isso? Quero dizer, como é que a gente faz alguém amar a gente?” (idem, p. 36). Para Pecola não era tão simples, ela não sabia como conseguir ser amada, pois durante onze anos de vida ela ainda não havia experimentado nenhum tipo de amor.

ESTAÉACASAÉVERDEEBRANCATEMUMAPORTAVERMELHAÉ
MUITOBONITAÉMUITOBONITABONITABONITABONIT

Passemos agora para o narrador onisciente em terceira pessoa, cuja 
narrativa é introduzida por fragmentos do texto inicial do livro. Esse fragmento acima fala de como é a casa de Dick e Jane, mas o narrador nos contará como é a casa de Pecola Breedlove. A descrição do espaço físico da casa dos Breedlove reflete todo o obscurantismo e apatia de suas vidas. O que surpreende na descrição da casa não é a simplicidade e a pobreza, mas a ausência de vida. É como se a casa fosse abandonada, como se ninguém a habitasse há muito tempo. Os móveis não têm uma história, não fazem parte de acontecimentos familiares comuns, como um armário em que o bebê entrava ou uma cama que quebrou quando as crianças pulavam sobre ela. Sobre os móveis o narrador diz: "Envelheceram sem jamais terem se tornado familiares" (idem, p. 39). Naquela casa não havia nenhuma boa recordação para alimentar a memória. A poeira que se acumulava sobre os móveis também cobria as almas tristes dos Breedlove.

\section{ESTAÉAFAMÍLIAAMÃEOPAIDICKEJANEMORAMNACASABRANCA EVERDEELESSÃOMUITOF}

A família Breedlove não morava em uma casa bonita e muito menos era feliz. Suas características físicas estavam fora de qualquer padrão de beleza. "A gente olhava para eles e ficava se perguntando por que eram tão feios; olhava com atenção e não conseguia encontrar a fonte. Depois percebia que ela vinha da convicção, da convicção deles" (idem, p. 43). Os Breedlove estavam convencidos de que eram agressivamente feios e estendiam sua feiúra física para toda a sua vida.

O narrador onisciente relata uma violenta briga entre os pais de Pecola, Pauline e Cholly Breedlove. Brigas com agressões verbais e físicas como essa fazem parte da rotina da família. As crianças, Pecola e Sammy, seu irmão mais velho, presenciavam as terríveis cenas de violência entre seus pais. Sammy tinha o ímpeto de fugir, já havia fugido várias vezes. Pecola apenas rogava a Deus que a fizesse desaparecer. "Por favor, Deus", sussurrou na palma da mão, "por favor, me faça desaparecer" (idem, p. 49). Na sua fantasia, ela conseguia desaparecer completamente com exceção dos olhos. "Por mais que tentasse, nunca conseguia fazer os olhos desaparecerem" (ibidem). Mas lhe ocorreu que se seus olhos fossem diferentes, bonitos, ela seria tratada de outra forma. Ela pensa em seus pais falando: "Ora, vejam que olhos bonitos os da Pecola. Não devemos fazer coisas ruins na frente desses olhos bonitos” (idem, p. 50).

Além da violência presenciada em casa há ainda nesse capítulo um 
episódio de violência simbólica. Um dia, ao ir comprar Mary Janes (um tipo de doce) em uma mercearia, Pecola sofre com o preconceito racial. O comerciante branco que a atende, a trata com desprezo e grosseria, quando ela lhe entrega o dinheiro ele hesita como se estivesse com nojo de tocar a mão da menina negra. Uma situação humilhante, mas que despertou em Pecola somente o sentimento de vergonha. A vergonha que, sozinha, não é suficiente para provocar uma reação.

E por fim temos, em Outono, a visita de Pecola às três prostitutas que moravam sobre a habitação dos Breedelove. Elas não desprezavam Pecola, eram razoavelmente atenciosas com a menina. Pecola, ainda ingênua, não entendia o que as mulheres faziam exatamente. Ela achava que elas tinham muitos namorados. Isso a intrigava e ela pergunta a Marie, uma das prostitutas, como ela fazia para ter tantos namorados. Sua curiosidade provinha do seu desejo em descobrir o que fazer para que alguém a amasse também. "Por que é que todos eles amam a senhora?" (idem, p. 56) Marie inventa uma história baseada nas suas lembranças de juventude para alimentar a curiosidade de Pecola. Mas a menina continuava a se perguntar. "Imaginou como seria o amor. Como é que os adultos agem quando se amam?" (idem, p. 61)

\section{Capítulo Inverno}

Nesse capítulo temos duas partes: a primeira, narrada por Claudia, e a segunda, pelo narrador onisciente. Claudia conta um episódio que mostra 0 desprezo racial dos próprios negros pela sua cor. Ainda crianças, eles já tem arraigado nas suas mentes a praga do preconceito racial que os consome e os enfraquece como um parasita, sem que eles se deem conta disso. $\mathrm{O}$ tratamento dado a um negro naquela época estava diretamente relacionado com a tonalidade da sua pele. Quanto mais escuro ele fosse, mais desprezado e humilhado ele seria.

Um dia, na saída da escola, Claudia e Frieda, acompanhadas por uma garota chamada Maureen Peal, presenciam uma cena de coação e violência verbal que um grupo de garotos negros dirigia a Pecola. Maurren Peal tem um papel importante nesse episódio, pois ela é o contraponto de Pecola. Maureen Peal é uma mulata claríssima, de longos cabelos castanhos, e considerada rica para os padrões das outras crianças. Ela era respeitada e admirada pelos meninos e meninas, e os professores a tratavam com amabilidade. Com Pecola 
acontecia o oposto, tratavam-na sem o mínimo de respeito.

Pecola é acuada como um frágil animal que está prestes a ser devorado por seu predador. Uma roda de garotos a cerca e a insulta. Curioso é que o tema central dos insultos é a sua cor, característica física comum a todos os meninos do grupo. Ao desprezá-la, eles estavam desprezando a eles mesmos. "Preta retinta. Preta retinta. Seu pai dorme pelado. Preta retinta, preta retinta, seu pai dorme pelado. Preta retinta..." (idem, p. 69)

Frieda vai em defesa de Pecola e enfrenta os meninos para ajudá-la. Claudia se encoraja e também vai defendê-la. Mas somente quando aparece Maureen Peal, a garota encantadora, é que eles recuam e vão embora.

VEJAOGATOESTÁMIANDOVENHABRINCARVENHABRINCAR COMAJANEOGATINHONÃOQUERBRINCARBRINCARBRINCAR BRINC

Essa parte do capítulo começa por uma descrição genérica de como eram as garotas apropriadas para se casar e trabalhar em casas de famílias abastadas. Elas eram magras e de pele parda. Frequentavam cursos para fazer o trabalho do branco com refinamento. Eram organizadas e extremamente caprichosas. Mas elas se tornavam tão profissionais que desempenhavam até mesmo seu papel de esposa e mãe como se cumprissem uma obrigação. Geraldine é o exemplo de uma dessas garotas. Ela atende perfeitamente a todas as necessidades físicas do marido e do filho, mas não vai além disso. Porém, todo o seu afeto é canalizado para um gato, seu animal de estimação.

Júnior, filho de Geraldine, percebe a diferença de tratamento dispensado para o gato e para ele. Isso o revolta e o leva a cometer gestos de crueldade. Um dia, ele convida Pecola para ir até sua casa para lhe mostrar alguns gatinhos. Os pais do menino não estavam em casa. Pecola fica admirada com a riqueza da casa. Júnior comete uma crueldade com a menina e com o gato ao mesmo tempo. Ele joga o gato no rosto de Pecola. Na tentativa de se agarrar, o gato arranha o rosto e o peito dela e cai. Pecola tenta sair de lá, mas o menino não permite. Ela acaricia o gato preto de olhos azuis e vê nele aquilo que ela desejava ter: olhos azuis. Júnior lança o gato sobre o aquecedor e ele morre. A mãe do garoto chega nesse momento e ele culpa Pecola pelo fato. Mais uma vez ela é humilhada e injustiçada. Era como se sua existência incomodasse as pessoas. 
Nesse episódio temos um exemplo de reação em cadeia, como a subjetividade de uma pessoa pode influenciar e mudar a subjetividade de outra. Geraldine, uma mulher que corresponde às exigências de um sistema social, reprimindo suas próprias vontades, acaba por transmitir ao filho sua frustração. O filho, por sua vez, transfere a sua insatisfação ao gato e a Pecola. Ela, por sua vez, internaliza tudo e vai se desconstruindo aos poucos.

\section{Capítulo Primavera}

Esse capítulo se divide em quatro partes: a primeira, narrada por Claudia, e as outras três, narradas pelo narrador onisciente. Claudia relata um episódio no qual a mãe de Pecola a agride e a maltrata. Um dia ela vai até a casa onde a mãe trabalhava, buscar roupas para estender. Claudia e Frieda presenciaram o que aconteceu. Claudia, com seu senso crítico, se revolta quando ouve a menina branca, filha da patroa, chamar a mãe de Pecola de Polly, enquanto Pecola, que era filha, tinha que chamá-la de sra. Breedlove.

Acidentalmente, Pecola derruba uma torta quente que sua mãe tinha acabado de fazer, ela se queima. No entanto, sua mãe não se importa com isso, bate nela e a expulsa de lá. A mãe de Pecola mostra-se mais preocupada com a sujeira e com a garotinha branca que chorava diante da cena a que assistiu. Quando a garota pergunta quem era, a sra. Breedlove responde: "Não se preocupe. Ninguém, meu bem" (idem, p. 111).

\section{VEJAAMÃEÉMUITOBOAZINHAMÃEQUERBRINCARCOMAJANE AMÃERIAMÃERIAMÃERI}

O narrador onisciente nos dá pistas da personalidade da mãe de Pecola e apresenta algumas cartas com a própria voz de Pauline. Esse recurso serve para ao menos tentar mostrar o que faz com que uma mãe seja tão cruel e indiferente com a própria filha. Não devemos entender isso como uma justificativa, mas podemos ver que o que ela se tornou é reflexo da vida que ela teve. Pauline Breedlove desde a infância era tratada com indiferença pela sua família. Ela acreditava que as pessoas a ignoravam por causa de um pequeno defeito físico no pé. Não chegava a ser manca, mas isso a incomodava.

Ela dedicou-se a fazer aquilo que mais gostava, fazer arrumação. Trabalhava em casa de famílias brancas e fazia tudo com tanta dedicação como 
se fora a sua própria casa. Sua satisfação era ser elogiada pelo seu trabalho. Pauline conheceu Cholly e no início foram felizes. Tiveram dois filhos, Sammy e Pecola. Cholly começou a beber e a ficar fora de casa. Ela buscou escape primeiro no cinema e depois na igreja. $\mathrm{O}$ cinema lhe deu conceitos de amor romântico e beleza física. "Ao igualar beleza física com virtude, ela despiu a mente, restringiu-a e foi acumulando desprezo por si mesma” (idem, p. 123).

Com a igreja ela interpretou Cholly como um modelo de pecado e fracasso, carregava-o como a coroa de espinhos, e os filhos como a uma cruz. "Todo o seu sentido de vida estava no trabalho, pois suas virtudes estavam intactas" (idem, p.130). Era como se sua verdadeira vida fosse aquela que ela tinha na casa dos patrões, sua família é que era a fantasia.

\section{VEJAOPAIELEÉGRANDEEFORTEPAIQUERBRINCARCOMAJANEO PAIESTÁSORRINDOSORRIAPAISORRIASORRIA}

Já sabemos que Cholly Breedlove é um homem bêbado e violento, mas nesse capítulo ele faz algo ainda mais desprezível: estupra sua própria filha, uma garota de onze anos. Um crime monstruoso para o julgamento da sociedade. Poderia haver alguma justificativa para tal comportamento? Da mesma forma como fez com Pauline, o narrador onisciente nos apresenta o passado de Cholly como uma maneira de pelo menos tornar suas atitudes um pouco compreensíveis.

Abandonado pela mãe aos quatro dias de vida sobre um monte de lixo ao lado de uma rodovia, Cholly foi resgatado por uma velha tia que o criou. Ela sempre o lembrava onde o havia encontrado. Mas era a única que o tratava com afeto. Sua tia morre quando ele ainda era adolescente. Então, ele resolve procurar o pai que nunca havia conhecido. É escorraçado como um cachorro pelo seu suposto pai, sofrendo a maior humilhação de toda a sua vida. Com esse fato é abalado física e psicologicamente. "Abandonado num monte de lixo pela mãe, rejeitado pelo pai por causa de um jogo de dados, não havia mais nada a perder. Estava sozinho com suas percepções e apetites, e só estes o interessavam" (idem, p.160).

Depois Cholly conhece Pauline e se casam. Mas ele continua a responder somente aos seus instintos, não há sentimentos. Quando os filhos nascem, o relacionamento, que já era frio, piora. Cholly fica desorientado com a chegada das crianças. "Como não tinha ideia de como criar filhos e como não fora criado por pai nem mãe, não conseguia sequer compreender o que 
esse relacionamento devia ser" (idem, p. 161). E numa tarde, quando ele chega bêbado em casa e vê Pecola de costas na pia lavando louça, tomado por um instinto animal, ele a domina e a estupra. Depois ele a cobre com um cobertor e a deixa caída no chão como desmaiada. Cholly não consegue ser pai, não aprendeu a ser pai, não teve nenhum referencial de pai.

\section{VEJAOCACHORROAUAUFAZOCACHORROAUAUFAZOCACHORRO QUERBRINCARCOMAJANEVEJAOCACHORROCORRERCORRA CACHORROCO}

Na parte final desse capítulo, o narrador onisciente nos apresenta uma personagem cuja "profissão" é enganar as pessoas. Conhecido como Soaphead Church, ele atende na sua casa as pessoas que buscam solução para problemas financeiros, sentimentais, de saúde, etc. Seu prazer é ver como ele consegue convencer as pessoas de que ele tem poderes. Soaphead é um mestiço descendente de ingleses. Ele teve uma boa educação e leu muitos livros, embora sua habilidade de interpretação fosse limitada. De todas as suas vítimas, Pecola foi, certamente, a mais prejudicada.

Um dia ela vai visitá-lo com a esperança de que ele pudesse realizar seu desejo mais acalentado - ter olhos azuis. Ela rezou a Deus por mais de um ano para ter olhos azuis, como Ele não a atendeu, ela resolve buscar outra fonte. O charlatão se sentiu tocado pelo pedido, jamais alguém havia desejado tal coisa. "De todos os desejos que já lhe haviam trazido - dinheiro, amor, vingança -, aquele lhe pareceu o mais comovente e merecedor de realização" (idem, p. 175). Soaphead dá a Pecola um pedaço de carne velha, no qual ele colocou veneno e diz a ela para dar ao cachorro que está na porta. Era um cachorro velho do qual ele queria se livrar.

Pegue esta comida e dê à criatura que está dormindo no alpendre. E cuide para que ele coma tudo. Preste atenção no comportamento dele. Se nada acontecer, você saberá que Deus recusou seu pedido. Se o animal se comportar de modo estranho, seu desejo será atendido dentro de um dia. (idem, p. 176)

Obviamente, o cachorro reage ao veneno que havia na carne e morre. Pecola, que já estava em um estágio avançado de alienação, vai embora acreditando que, finalmente, conseguiu seus tão desejados olhos azuis. 


\section{Capítulo Verão}

Esse é o último e mais curto capítulo do livro, nele há a parte introdutória narrada por Claudia, um longo diálogo entre Pecola e seu amigo imaginário e, por fim, Claudia fazendo suas considerações sobre o que aconteceu com Pecola. Naquele verão, Claudia e Frieda saíram pelas casas da vizinhança para vender pacotinhos de sementes. Elas receberam uma promessa de que se vendessem todas as sementes, ganhariam uma bicicleta. Durante suas passagens pelas casas, ouviam trechos de uma terrível história e aos poucos foram unindo esses trechos e perceberam que a história se referia a Pecola.

Dessa forma, as meninas descobriram que Pecola estava grávida de seu pai e ainda havia sido espancada pela mãe pelo acontecido. Além disso, as pessoas a consideravam culpada também pelo que aconteceu e desejavam que seu bebê não sobrevivesse. Claudia e Frieda ficaram comovidas com a dureza de coração das pessoas, pois elas queriam que o bebê nascesse bem. Elas ainda não compreendiam o processo de se ter um bebê de um homem, mesmo que esse homem fosse seu próprio pai. As meninas, na sua natural solidariedade infantil, decidem fazer uma promessa para que o bebê de Pecola não morresse. Elas abrem mão do dinheiro das sementes como sacrifício da promessa e plantam as sementes no fundo de casa, se as sementes brotassem elas saberiam que tudo deu certo. Mas aquelas sementes nunca brotaram.

\section{OLHEOLHEAÍVEMUMAMIGOOAMIGOVAIBRINCARCOMAJANE ELESVÃOJOGARUMJOGOGOSTOSOBRINQUEJANEBRINQUE}

Nessa parte não há intervenção do narrador onisciente. Ocorre o discurso direto reproduzindo a voz de Pecola e do amigo imaginário criado por ela. Depois de passar por vários processos de desconstrução de identidade, Pecola se aliena completamente do mundo real, o mundo que a destruiu. Ela cria outro mundo como uma forma de se proteger do mundo real. Ela não se dá conta que está grávida, recusando-se a lembrar de ter sido violentada pelo pai. As pessoas a desprezam porque ela está grávida do pai, mas ela acredita que é porque todos têm inveja dos seus olhos azuis. Toda a sua atenção se concentra em seus olhos azuis. Ela passa horas se olhando no espelho, admirando seus olhos azuis que na verdade não existem. Seu amigo tem a função de confirmar que os olhos azuis dela são os mais azuis e os mais bonitos. "E foi assim. Uma menina negra anseia pelos olhos azuis de uma menina branca, e o horror 
no cerne do seu desejo só é superado pelo mal da realização" (MORRISON, 2003, p. 204).

Para finalizar esse capítulo, Claudia, agora no momento da enunciação, analisa e avalia o que aconteceu com Pecola. A narradora considera todos culpados, inclusive ela mesma. "Todos nós - todos os que a conheceram - nos sentíamos tão higiênicos depois de nos limparmos nela. Éramos tão bonitos quando montávamos na sua feiúra" (idem, p. 205).

Depois de analisarmos a estrutura de O Olho Mais Azul, podemos dizer que Toni Morrison realizou, impecavelmente, seu trabalho arquitetônico. Ela inovou na divisão dos capítulos e ousou no tema que era tabu para a época. O jogo de vozes narrativas deu equilíbrio e leveza ao romance, além de um narrador complementar a fala do outro. $\mathrm{O}$ ciclo das estações do ano se compara ao próprio ciclo da obra que se encerra no mesmo período de tempo. Assim como uma pintura que se contempla ou uma melodia que se aprecia, esse romance é digno de toda admiração que uma obra de arte merece.

\section{Referências}

BAKHTIN, Mikhail. Estética da criação verbal. [Trad. Paulo Bezerra]. São Paulo: Martins Fontes, 2003.

Questões de literatura e estética: a teoria do romance. [Trad. Aurora Bernardini e outros]. São Paulo: Ed. UNESP, 1998.

ECO, Umberto. Seis passeios pelos bosques da ficção. [Trad. Hildegard Feist]. São Paulo: Companhia das Letras, 1994.

FORSTER, E.M. Aspectos do romance. [Trad. Maria Helena Martins]. Porto Alegre: Globo, 1969.

MORRISON, Toni. O olho mais azul. [Trad. Manuel Paulo Ferreira]. São Paulo: Companhia das Letras, 2003.

Recebido para publicação em 8 nov. 2010.

Aceito para publicação em 14 dez. 2010. 